\title{
Introduction
}

\section{Trauma Trails and Memory Walks}

Maria Pia Di Bella CNRS-IRIS-EHESS, Paris

Places of traumatic or miraculous events have often become sites to be visited by the victims or the faithful who were part of the event, by their heirs, by the community, or by strangers and tourists who feel compelled to come in order to better understand the event. Sometimes monuments are constructed on the physical site of the event to underline its historical importance and the necessity to remember it. Often, in a city or a geographic area, the traumatic events have taken place in different localities, giving rise to a trail that people follow in order to commemorate the event (from Jerusalem's Via Dolorosa to Boston's Freedom's Trail).

Places or trails of traumatic or miraculous events are thus constantly visited, giving rise to processions, organized pilgrimages, or personal journeys. This issue of Journeys intends to focus on the places or trails where traumatic or miraculous events took place, and on the significance and meaning people put in the act of walking to and around these sites. We in fact wish to combine the act of walking to the process of remembrance in order to discuss how these two voluntary actions intertwine. We are of course driven toward the modern thinkers who aptly wrote about walking, ranging from Jean-Jacques Rousseau, Henry Wadsworth Longfellow, Charles Baudelaire to Søren Kierkegaard, Henry David Thoreau, and Walter Benjamin. ${ }^{1}$

But the walking discussed in this special issue is neither the one done "in the distant woods or fields, in unpretending sprout-lands or pastures tracked by rabbits," ${ }^{2}$ nor the one done as flâneurs in Paris streets (Baudelaire), but the one performed during secular or religious pilgrimages. Religious pilgrimages usually attract people in specific places filled with the aura or the energy of past miraculous or exceptional events. We have all 


\section{Introduction}

heard the names of Jerusalem, Rome, Saint-Jacques de Compostelle, or Mecca as main places for religious pilgrimages. But as contributors to this issue show, secular pilgrimages serve also other purposes.

The articles published in this issue were first presented at the American Anthropological Association's (AAA) 2010 Annual Meeting in New Orleans by Cheryl Finley, Sandra L. Zimdars-Swartz, and myself. Two of the speakers who presented in New Orleans are not included in this issue-Baber Johansen (Harvard Divinity School) and Jonathan Skinner (Queen's University Belfast), as well as our chair, David A. Kideckel (Central Connecticut State University). Two authors who were not presenting in New Orleans have been added to the project: Michael Jackson and Maja Petrović-Šteger.

The discussant of our AAA session, Nigel Rapport (University of St. Andrews), was one of the first to launch this topic in Journeys-in a special issue co-edited with Andrew Irving (University of Manchester) and Atreyee Sen (University of Manchester): "Sense of Spatial Equilibrium and the Journey: Confounded, Discomposed, Recompose." His own contribution in that issue, "Walking Auschwitz, Walking without Arriving,"3 should be read alongside with ours by readers wishing to go further on the topic of trauma trails and memory walks.

With the integration of Jackson's now classic chapter, titled "In the Footsteps of Walter Benjamin," 4 we want to make a statement on how we view the project "Trauma Trails and Memory Walks." Finley's article on the impact of art, performance, and technology on the global transformation of heritage tourism in recent years-especially the sites of memory deemed important to diasporic Africans-adds an important dimension to the project. And my article on Berlin's "Holocaust trail" shows how a town-where the Holocaust's conceivers and executers produced it in loco-deals with its incompressible heritage.

Historically, walking has been an essential element of Christian pilgrimage, as Zimdars-Swartz reminds us. For medieval journeys of faith, whether from London to Canterbury, Santiago de Compostela, Rome, or Jerusalem, the rigors of walking the distance from home to site could demonstrate suffering, sacrifice, and devotion. As if the faithful try to reproduce the saints' vertical ascent to heaven by their own horizontal locomotion.

Maja Petrović-Šteger's article analyses contemporary conceptualizations of death and grieving within modern informational economies, the etoy "Mission Eternity Project" that created a mobile sepulchre to investigate 
and challenge conventional practices of the disposal of the dead and their memorialization. Her article-as she underlines—seeks to generate terms for discussing how new artistic, digital, and forensic technologies can reconfigure the more ordinary ways of dealing with the dead. And tout naturellement it brings us a step forward, where actual locomotion is replaced by a web search.

The "walking" we are interested in has its mythical roots in the Bible's episode of Adam and Eve's transgression. ${ }^{5} \mathrm{~A}$ way of interpreting this transgression is to see it as an allegory of the primates (Homo sapiens) separation from their ancestors; as a description reliving the dramatic moment when they separated from other primate species, left the trees, stood on their hind legs, started using their hands: an allegory of how, thanks to this hand, they were able to seize the apple being finally in an upright position; as a historical event in which frightened humans were hardly able to foresee their future now that they stood on their own two feet-a future where men would have to till the land in order to eat, and women to give birth in pain because of their changed pelvis. Through this interpretation we can realize that the event that shook mankind was not the eating of the apple but the grasping of the apple, the upright posture that enabled humans to pick the apple. Such was the curse that befell Homo sapiens.

After their fall from the trees, humans wandered, crossing rivers, valleys, mountains, continents, and seas. Some began to regret the happy days when they capered among the branches of the trees. Others left traces of their passage: totems, statues, altars, temples, pyramids and towns; traces of the instruments enabling them to travel: carriages, ships, trains, cars and planes; traces of their transformations, for they were Egyptians, Romans, Spaniards, or British; and traces of their ill deeds, for they killed and slaughtered their fellowmen. ${ }^{6}$

We are indeed making and remaking the journey begun by our forefathers. Sometimes in a different spirit or in less dramatic ways. Often, the compulsion that was there is still here. And the belief in the necessity of walking, overwhelming. Without forgetting the requisite of "standing up."

The generations that went through World War I and World War II were certainly shell-shocked by their experience. The following generations started trends that somehow still seem to survive: from the Beat Generation to youth counterculture, or from hippie trails (Kabul to Kathmandu) to backpack tourism. On the Road-Jack Kerouac's 1957 novel based on his travels 


\section{Introduction}

across America-is a classic that resonates with each young generation wishing to leave the routine of their daily life in order to see the world.

In addition to walking, running has also become a major trend in the United States (and elsewhere) since the 1908 Summer Olympics. And "Frank Shorter's victory in the marathon at the 1972 Summer Olympics spurred national enthusiasm for the sport." Within the United States, an estimated 467,000 runners completed a marathon by 2009, and nowadays various marathons are held all around the world on a nearly weekly basis. ${ }^{8}$

The reason marathons are mentioned in the introduction to this issue is that they are increasingly linked to victims' memorials, and this makes them an important addenda to our topic. Take, for example, the New Mexico National Guard Bataan Memorial Museum, dedicated to the US and Filipino prisoners who died during the Bataan Death March. ${ }^{9}$ To honor the memory of the service members who defended the Philippine Islands during World War II, every year, in early spring, a rigorous 26.2-mile march/run is conducted at White Sands Missile Range, New Mexico. ${ }^{10}$

More recent events are also honored with a marathon: the bombing at Oklahoma City of the Alfred P. Murrah Federal Building at the initiative of Timothy McVeigh and Terry Nichols, on 19 April 1995 that killed 168 people. It is in fact the Oklahoma City National Memorial \& Museum, the victims' families and the survivors that host the Oklahoma City Memorial Marathon:

From its inaugural race in 2001 with just shy of 5,000 participants, the 2011 event hosted nearly 25,000 runners and walkers from 49 states and six foreign countries. The mission of the Oklahoma City Memorial Marathon is to celebrate life, reach for the future, honor the memories of those who were killed and unite the world in hope. ${ }^{11}$

In remembrance of the victims of 9/11 terrorist attacks on New York City, the State University of New York at Binghamton hosts annually a Mitzvah (good deed) Marathon. The marathon runs from 11AM to 5PM and is designed to present members of the campus community with opportunities to do a good deed in memory of 9/11 victims. Participants in the marathon fill out a form documenting their efforts. It is then attached to a picture of a 9/11 victim and placed along a memory wall erected on the walkway near the fountain honoring the thirteen Binghamton University alumni who tragically lost their lives on that fateful 2001 day. ${ }^{12}$ 


\section{Notes}

1. Walter Benjamin (1892-1940) lived during his childhood in Schöneberg, then in Charlottenburg (near Savigny Platz), and later on in Grunewald. When he came back to Berlin, in the 1930s, he lived at Prinzregentstrasse 66 (Wilmersdorf), where there is a plaque in his honor. There is also now a square named after him in Berlin, Walter-Benjamin-Platz, located parallel to Kurfürstendamm, in between Liebnitzstrasse and Wielandstrasse, steps away from Oliver Platz (Charlottenburg-Wilmersdorf). See Walter Benjamin, Berlin Childhood around 1900 (Berliner Kindheit Um Neunzehnhundert). Trans. Howard Eiland (Cambridge, MA: Harvard University Press, 2006).

2. Henry D. Thoreau, Walden. A fully Annotated Edition, edited by Jeffrey S. Cramer (New Haven: Yale University Press, 2004), 131.

3. "Walking Auschwitz, Walking Without Arriving," Journeys: The International Journal of Travel and Travel Writing 9, no. 2 (2008): 32-54.

4. See Michael Jackson, Excursions (Durham and London: Duke University Press, 2007), 1-21. We thank Duke University Press for allowing the reprint of Jackson's chapter.

5. For the Bible version, see Genesis 2:3.

6. Abridged from Maria Pia Di Bella, "Exhibition Heloisa Novaes," Journeys: The International Journal of Travel and Travel Writing 2, no. 1 (2001): 114-118.

7. "Marathon," Wikipedia (http://en.wikipedia.org/wiki/Marathon [accessed 4 October 2012]).

8. Ibid.

9. "The Bataan Death March was a forced march of 90,000 to 100,000 American and Filipino prisoners of war captured by the Japanese in the Philippines in the early stages of World War II. Starting out from Mariveles, on the southern end of the Bataan Peninsula, on April 9, 1942, they were force-marched 55 miles (88 km) to San Fernando, then taken by rail to Capas, from where they walked the final 8 miles (13 km) to Camp O’Donnell. They were starved and mistreated, often kicked or beaten on their way, and many who fell were bayoneted. Only 54,000 reached the camp; 7,000-10,000 died on the way and the rest escaped to the jungle" (http://www.britannica.com/EBchecked/ topic/55717/Bataan-Death-March\#84289 [accessed 4 October 2012]).

10. Quoted from “Bataan Death March,” Wikipedia (http://en.wikipedia.org/wiki/Bataan Death_March [accessed 4 October 2012]). "The Bataan Death March had a large impact on the state of New Mexico. Eighteen hundred New Mexico soldiers from the 200th/515th Coast Artillery of the National Guard were deployed to the Philippines in WWII. Only half these soldiers survived, and within a few years after the war almost one half more had died" (ibid.).

11. "We Run to Remember," http://www.okcmarathon.com/RaceInfo/tabid/58/Default.aspx (accessed 4 October 2012). For an account on the "memorialization of the bombing," see Edward T. Linenthal, The Unfinished Bombing: Oklahoma City in American Memory (Oxford and New York: Oxford University Press, 2001).

12. “9/11 Campus Wide BU Commemorative Program,” http://www.newschannel34.com/ content/developingnews/story/9-11-Campus-Wide-BU-Commemorative-Program/ y8aq62tSSkG3F7l3Hw1_dw.cspx (accessed 4 October 2012). 